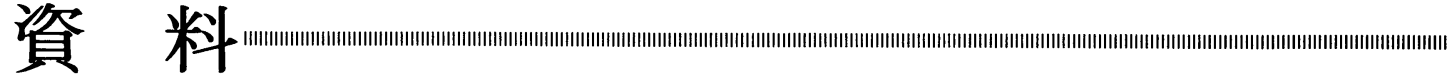

\title{
スポーツと高分子
}

棚 橋 良 次*

1.は じめに

スポーツ用具の多くは，いくつかの異なる物性を持っ た材料を組合せて，一体複合化したものである. 使い手 にとって，用具はあたかも身体の一部のように挙動する ものをよしとする.人が異なり使用条件が変われば，そ れに見合った用具が本来は一対一で対応する。

かつては単一素材 (天然材料)でできていた用具は，素 材の複合化により高性能化がはかられ，今日に至ってい る.ここでは複合化による進歩を具体例として，スキ 一，テニスラケット，及びゴルフクラブをとおして，根 拠となる物理特性をもまじえて述べてみたい。

\section{2. 複合構造の意義}

一体化複合構造とは何を意味するか。まずその基本と するところを，軽量高剛性の立場から考える。

ここで，2 種類の相異なる材料の組合せ方と，接着の 有無によって，剛性がどのように変わってくるかを検討 する(図 1)。A は，ポリウレタン発ぽら体(厚み: 10 $\mathrm{mm}$, 幅: $\mathrm{B}$, 弾性率: $80 \mathrm{~kg} / \mathrm{mm}^{2}$ )を $\mathrm{FRP}$ (厚み: 1 $\mathrm{mm}$, 幅: B, 弾性率 : $3,000 \mathrm{~kg} / \mathrm{mm}^{2}$ )で両側から重ね合 わせた試験片であり，B 合わせたものである。また， C は，同じ発ぽう体の半分 の厚さのものを 2 枚用意して，A，B と同じFRP 2 枚を 中芯として，両側から発ぽら体でサンドイッチして，そ の各々の界面を接着剤で貼り合わせたものである．この 三つの試験片の曲げ剛性を計算し，比較すると，Bが最 も剛性が大きく，Aの約150倍， C の14倍である。よっ て，まずもって接着の意義と素材の配置が，どんな役割 を果しているかがわかるであろら。

\section{1 曲げ剛性の式}

上記の計算結果を理解するため，曲げ剛性の一般式を 導くと，せん断変形の成分が無視できる場合 (中芯が柔 かくない)は，次式のごとくなる(図 2).

$$
\overline{E I}=\sum_{i=1}^{n} E_{i} I_{i}=\sum_{i=1}^{n} E_{i} \int_{x_{i-1}}^{x_{i}} \int_{y_{i-1}}^{y_{i}}\left(y-y_{c}\right)^{2} d y d x
$$

相知なる 2 程頪の材料の組合わせ

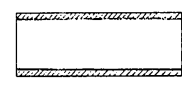

而小合わせ

$\mathrm{F}+\mathrm{PU}+\mathrm{F}$

$\mathrm{E} 1 . / \mathrm{B}=0.13 * 10^{4} \mathrm{~kg} \cdot \mathrm{mm}$

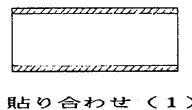

$F \cdot P U \cdot F$ c

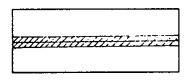

貼り合わせ (2) $P U \cdot F \cdot F \cdot P U$
$I_{B} / E I_{C}=14$ $t_{F}=1 \mathrm{~mm}$

図 $1 \mathrm{~A}, \mathrm{~B}, \mathrm{C} 3$ 種類の複合構造の曲げ剛性の比較

ひずみ分布

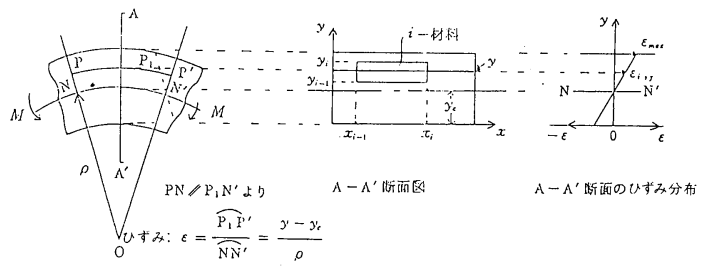

図 2 曲げモーメントが作用した場合の $\mathrm{A}-\mathrm{A}^{\prime}$ 断 面のひずみ分布と中立軸 $\mathrm{y}_{\mathrm{c}}$ の位置

$$
y_{c}=\frac{\sum_{i=1}^{n} E_{i} \int_{x_{i-1}}^{x_{i}} \int_{y_{i-1}}^{y_{i}} y d y d x}{\sum_{i=1}^{n} E_{i} \int_{x_{i-1}}^{x_{i}} \int_{y_{i-1}}^{y_{i}} d x d y}
$$

$y_{c}:$ 中立軸

$E_{i}: i$ 番目の材料の曲げ弾性率

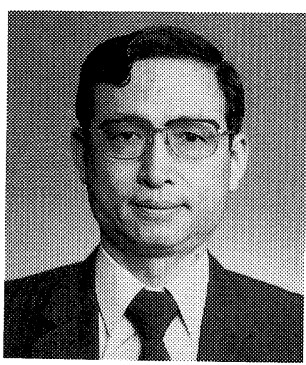

日本楽器製造株式会社 ( $\overline{\boldsymbol{\top}}$ 432 静岡県浜松市西山町 1370) スポーツ事業部技術 部. 昭和37年静岡大学文理 学部物理学科卒業. 同年, 日本楽器製造(侏入社, 現在 に至る。 
試験片 A，B，Cについて，この式より容易に計算で き，その差がわかるであろう．A FRPの中央にそれぞれ一つと中芯の中央に一つあり， その結果 FRP に発生するひずみが小さいためである. B は接着により，FRPが大きくひずむので剛性が大き くなる，C はひずみが小さい位置に高弾性素材があり， ひずみが大きい位置に低弾性素材があるためである.

\section{2 スポーツ用具の構造}

生物は環境への順応や，生存への対応として，進化と 棲み分けをして，今日の姿態を呈している.

視点を構造におけば，鳥の羽根や，麦の茎等にみられ るように，軽量高強度高剛性構造である(図 3 ).

これらの構造は試験片 Bに相当する.もしこのよう な構造を自然が選ばなかったならば，鳥は飛べなかった し，麦は穗を風に対し支えきれなかったはずである。こ のことを考学ると自然が如何に効果のよい構造と素材の 配置をとっているかがわかる。

スポーツ用具の構造は, 用具に求められる要求特性へ の対応として, 用具によってはかなり複雑な構造と素材 の選択をしており，この基本的考えは自然から学ぶとこ ろが多い.

\section{3. 要 求 特 性}

用具が力を受けると変形し，エネルギーを貯えて，や がてそれを放出して止まる，あるいはスキー等のように 連続負荷を受けながら挙動する。これらは多くのスポー ツ用具に共通したプロセスである。このときの用具の挙 動は, 使い手や外的条件によって変わるが本質的には用 具の持っている固有性によって定まる。よって，固有性 と挙動の関係は, 用具の設計上きわめて重要である. 後 にこの点について触れる.

固有性を形成する要因を挙げると下記の特性が考えら

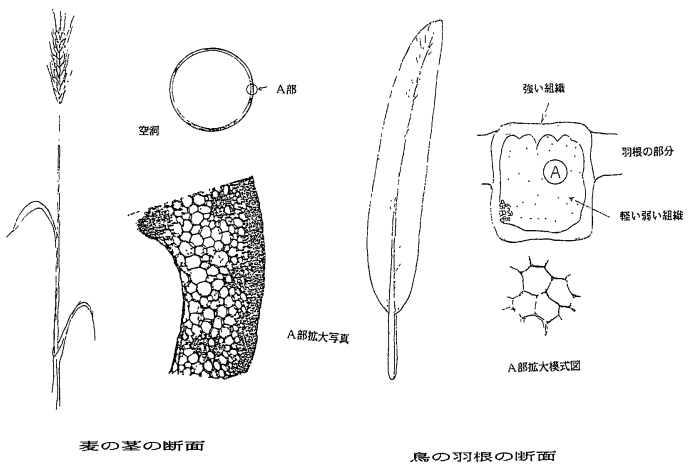

図 3 生物の軽量高剛性構造の例
れる。

i ) 形状

ii）重量(絶対重量とその分布)

iii） 剛性(曲げ剛性分布と捩れ剛性分布)

iv）動特性（振動特性と内部粘性）

v）強度（静荷重強度，衝撃強度及び疲労強度）

vi) 環境安定性(熱, 光線, 温度, 等の影響による特 性や強度の安定性)

実際に人が使用して感ずる特性は i ) 〜iv)によって定 まり，v），vi）は品質に関する物理量で, 固有性を形成 する.

\section{1 設計の自由度}

要求特性を具現する設計の自由度は 4 つである.

i ) 外形寸法の決定.

ii ） 構成材料の選択と配置

iii）曲げ剛性分布，ねじれ剛性分布，重量分布など の諸特性の中のどれか一つの特性，例えば曲げ 岡性分布.

iv）製造方法

この 4 つ自由度のそれぞれをどのよらに設計するか によって, 用具の固有性が变わり, その結果使用性能が 変わる.この中で理解しにくい自由度に製造方法がある ので，これについてのみ述べる(図 4)。

複合構造では製造法によって, 用具内部に分布するエ ネルギーの形態が異なる場合がある．左図(1)はFRPを プリプレグの状態で，木中芯の両側からサンドイッチし て成形する場合である、プリプレグが硬化するさい，樹 脂が収縮しょうとするが，中芯との界面で接着が生ずる ため，自然状態のようには収縮しきれない。よって，中 芯に対してはFRP は引張った状態で貼ったと同じこと になり, 結果は応力のバランスから FRP に引張り応力 が，中芯に圧縮応力が発生し，それぞれに内部ェネルギ 一を貯えた形態で複合体が生れる。それに対して図 (II) では，硬化した FRPの上下面間にポリウレタンを注入

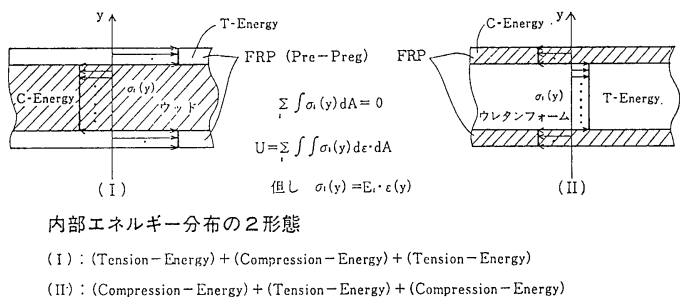

図 4 製造法の差からくる内部エネルギー分布の 2 形態 
し発ぽらさせると, ウレタン発ぽら体が硬化時に収縮す るが，FRPとの接着のため収縮しきれないで，テンシ ョンのかかった状態, すなわちテンションェネルギーを 貯えた形態で, FRPにはその逆のコンプレッションェ ネルギーを貯えた複合体となる。（I）とは逆のエネルギ 一の存在形態である。これは材料及び製造法の違いから エネルギー形態の異なることを示したことになるが，更 にほり下げて話を進めると，この同じ材料に拉いて，も し（Ｉ）でプリプレグを先に硬化させて FRP とし，その 後中芯と接着剂で貼り合わせると，ほとんど内部ェネル ギーは貯えられないことになり，実際の使用感でレスポ ンス(作用に対する反作用の時間的推移)が大きく異なる ことを見出している.（II）の場合においても，先に中芯 をインジェクションしておいて，後に上下の FRPを貼 った場合は (I ) と同様に内部エネルギーの貯光具合が小 さくなってくる. これらの差異は, 用具の挙動に微妙に 影響を与え, 人間の感覚には大きな差となって現われる.

\section{4. 最適複合化}

複合化の本来の目的は, 不完全なものをより完全なも のへと近づけることである，具体的には，理想的固有性 の追求である. この手段として，用具を構成する材料の 種類とその物性が問題となる. かつて単一材料でできて いた用具が不完全だとすれば，ぞのような点で不完全な のか，強度か，自分の意志ど打りにレスポンスしないの か，耐久性なのか，これらを明らかにした後，どのよう な解決の仕方があるか，それを見出すことである．最適 複合化は, 最終的には素材の選択とその最適寸法及びそ の最適配置を意味し，できた用具は動的物理量として伝 達関数でもって，その固有性の一部を表現することがで きる．ここでは伝達関数について述べ，スキーとテニス ラケットについてその挙動をみる.

\section{1 伝達関数}

固有性の動特性を表わす物理量に伝達関数がある。あ る系 $G$ に入力 $\gamma(t)(t$ : 時間) が作用した時, 出力 $C(t)$ が 得られる. 一般に微小入出力について, 系 $G$ は線形常 微分方程式で表現できる.

$$
\begin{aligned}
b_{n} \frac{d^{n} C(t)}{d t^{n}}+b_{n-1} \frac{d^{n-1} C(t)}{d t^{n-1}}+\cdots+b_{1} \frac{d C(t)}{d t}+b_{0} C(t) \\
=a_{m} \frac{d^{m} \gamma(t)}{d t^{m}}+a_{m-1} \frac{d^{m-1} \gamma(t)}{d t^{m-1}}+\cdots . \\
\quad+a_{1} \frac{d \gamma(t)}{d t}+a_{0} \gamma(t)
\end{aligned}
$$

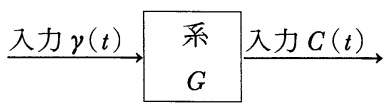

制御系表示

Laplace 交換すると

$$
\begin{gathered}
\left(b_{n} s^{n}+b_{n-1} s^{n-1}+\cdots \cdot+b_{1} s+b_{0}\right) C(s) \\
\quad=\left(a_{m} s^{m}+a_{m-1} s^{m-1}+\cdots \cdot+a_{1} s+a_{0}\right) R(s) \\
G(s)=\frac{a_{m} s^{m}+a_{m-1} s^{m-1}+\cdots \cdot+a_{1} s+a_{0}}{b_{n} s^{n}+b_{n-1} s^{n-1}+\cdots \cdot+b_{1} s+b_{0}}
\end{gathered}
$$

入力 $R(s)$, 出力 $C(s)$ に対して,

$$
\begin{gathered}
C(s)=G(s) \cdot R(s) \\
G(s) \text { : 伝達関数 }
\end{gathered}
$$

\section{$\stackrel{\text { 入力 } R(s)}{\longrightarrow} G(s)$ 出力 $C(s)$}

伝達関数による表示

モーダル解析では, 測定によって伝達関数を求めるこ とがでさる. その結果, 用具のもつ固有振動数を求めた り，その各々の固有振動数における粘性係数に関する物 理量として, $\tan \delta(\delta:$ 系の位相遅れ)が求まる。

また，各固有振動数における挙動をアニメーションで 見ることができるので用具の性能解析に役立つ.

ここではテニスラケットの挙動とスキーの挙動につい て，検討してみることにする(図 5).

i ） テニスラケットの挙動

図 5 はあるテニスラケットについての自由振動の測定 から求めた伝達関数である. 最初のピークは $f_{1}=101$ $\mathrm{Hz}$ で一次の固有振動数であり, フェイス側の節がスイ ートスポットに対応するが，実際はグリップする位置の 関係からこれより少し下方である.2つ目のピークはガ ットの振動で約 $150 \mathrm{~Hz}$ である. 3 つ目の固有振動数は, フィーリングに関係する振動で，どのよらにコントロー ルするかは素材の選択と設計にかかっている.

\section{ii ） スキーの挙動}

伝達関数から, 最初の 3 つの固有振動数について, 振 動モードを描いた。 スキーの場合の振動の評価は非常に 難かしく，雪質との相関において論ずべきもので，よく 滑べるためには，振動は大切な物理特性でもある。内部 粘性の大きいスキーは滑りが悪いのは実験結果からも， 実証済みである。この理由については本題からはずれる ので，事実のみの記述にとどめる.

次に複合化において，構成材料が異なれば伝達関数が 異なることを図 7 より読みとることができる.

これは曲げ剛性を同じにしたスキーであるから，静的 物理量は，基本的に同じに設計されている．動的物理量 

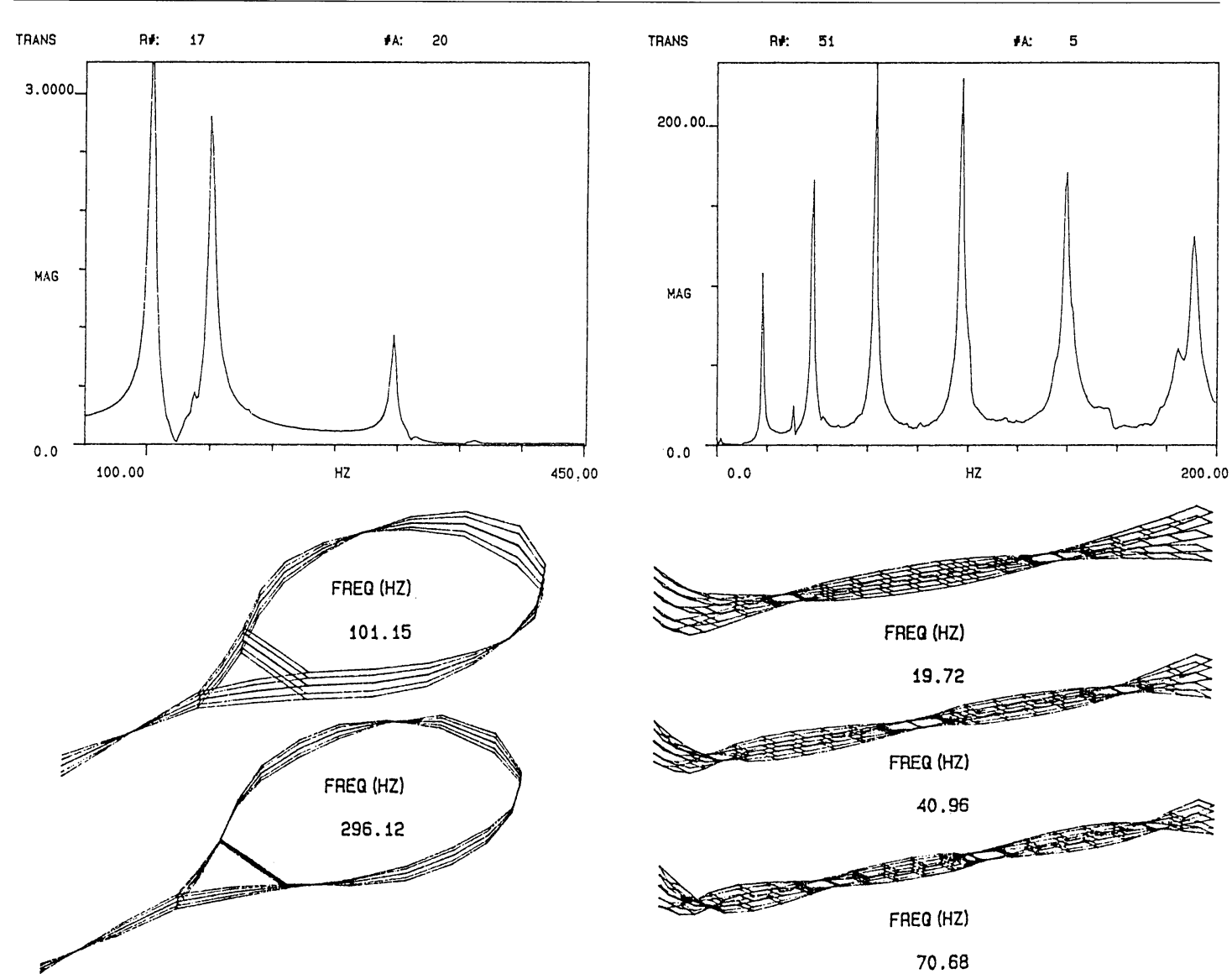

図 5 テニスラケットの伝達関数とフレームの一次 と二次の振動モード. $150(\mathrm{~Hz})$ のピークはガ ットの振動

図 6 スキーの伝達関数と一次, 二次, 及び三次の 振動モード

としての伝達関数では, 一次の固有振動数が静的曲げ剛 性に相当し，二次以上の高調波に材料構成の差がでてい る. この両スキーを試乗した場合, 乗り手は随分異なる 性質を感ずる. この例からも最適複合化の過程で伝達関 数が大きな役割を果していることがわかる.

\section{5. 具 体 例}

スキーはスポーツ用具の中で最も複雑な材料構成と構 造を選んでいる(図 8). その理由を一ロでいえば，スキ 一の要求特性が㛜しく，かつ高いからである.どらして そらなのかといえば, 雪の焼結現象が起こるー $2^{\circ} \mathrm{C}$ 前後 の雪がシーズン中必らず出会ら雪だからである． $0{ }^{\circ} \mathrm{C} に$ 近い雪は，手で握ると容易にかたまりができるが， $-5^{\circ} \mathrm{C}$ 以下の雪ではさらさらと指の間から落ちてしま ら. スキーをする場合この差ははっきりと操作性に現わ れてくる．前者のかたまる雪は, 粘っこくエッジングの い) 
棚橋良次

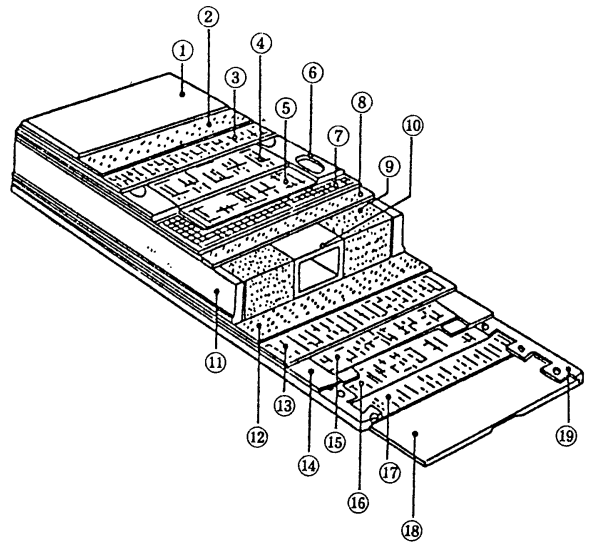

1,11, フェノール・シート

$2,8,12$, エポキシ・シート

$3,4,5,7,13,15,16,17$ 各種ガラスFRP

6, アルミ・トップエッジ

図 8 競技用 FRP 三次元空胴構造スキー

際に破壞しにくい。これは操作が難かしいことに対応す る.それに対して，後者の雪は，切削性のよい材料のよ らに，さくさくと破壊し，少々下手にターンをしても， 雪が崩れて，あたかも旨く操作できたよらに回転ができ るのである。このように雪は12月の新雪から 3 月のざら め雪まで, 時間の経過につれ新雪は昇華現象をと扎して しまり雪に，3 月に入ると昼間の融解と夜間の凍結を繰 り返して，乙まり雪はザラメ雪へと変化して，物性を変 える、このような雪が，スキーの対象であり，どんな雪 でも満足できる性能を備えることが要求されるため，最 適設計が一段と厳しいのである.

具体的に複合化の話しに入ろう.図 8 は競技用スキー の断面図である．全部で19のパーッで 9 種類の材料から できている。このうちの一つ GFRP には 5 種類のガラ ス繊維が使われている，概略その役割を説明すると(1) フェノール積層板は表面材としての役割，すなわちデザ インのしやすさ，傷のつきにくさ，耐水性，及び耐候性 が要求されるが，一番外側に位置する関係から，挙動時 のひずみが大きい。これは粘弾性寄与率が大きいこと で，薄いながらも重要である．次にFRPとその使用量 は, 中級以上のスキーの場合は強度的に充分であり, 使 用性能中心の設計となる。この構成で，もし FRP の種 類とか使用量を変えたなら，性能は大きく変わる。すな わち，全体の材料のなかでバランスがとれて，競技用ス
キーに適した構成になっているからである，(100 FRP 空胴構造はせん断剛性を強める役割と, 軽量化による変 形回復速度に対応する. (9)の゚リウレタン発泡体はこの 速さを押さえる働きと振動吸収の働きの双方を受けも つ、等々各パーツはそれぞれの役割を持っている.

\section{2 テニスラケット}

スキーで複合化を代表して説明したので，テニスラケ ットとゴルフクラブでは, 複合化の成果を中心に述べる.

この10年の間に，テニスラケットの FRP 化の動きは 目覚しく, 特にこの 3,4 年は形状のオーバーサイズ化 により，性能差が歷然としてきた．FRPの採用により 設計の自由度が増して, 機能の幅が広がったため, ビギ ナーにとってはプレーが楽になり，エキスパートにとっ ては，より自分の個性に合ったラケットを選べる時代と なった，具体的に数值で性能差を示そう(表 1).

形状のオーバーサイズ化, 素材の FRP 化によって, 80\%スポットの広さが増大していることがわかる．フレ 一ム面積が大きくなると, ガットテンションを従来のコ ンベンショナルなものに比較して，20４0\%アップする 必要がある，そのため，そのテンションに耐えるだけの 剛性を持たなければならない。これを具現するためには CFRP が最適であり，他材料では重くて，ラヶットの性 能を著しく落すことになる(表 2). 具体的な構造に関し

表 1 各種素材と形状の大小による スイートスポットの広さの比較

\begin{tabular}{r|c|c|c|c|c}
\hline & $\mathrm{A}$ & $\mathrm{B}$ & $\mathrm{C}$ & $\mathrm{D}$ & $\mathrm{E}$ \\
\hline スポット反発率 & 0.9 & 0.9 & 0.9 & 0.9 & 0.9 \\
\hline $80 \%$ スポット広さ \\
$\begin{array}{r}\left(\mathrm{cm}^{2}\right) \\
\hline \text { 玎 }\end{array}$ & 26 & 32.5 & 39 & 49 & 58.5 \\
\hline $\begin{array}{r}\text { 面 積 } \\
\left(\mathrm{cm}^{2}\right)\end{array}$ & 450 & 450 & 450 & 620 & 620 \\
\hline
\end{tabular}
$\mathrm{A}:$ 木製標準サイズ
$\mathrm{B}:$ 金属製標準サイズ
$\mathrm{G}: \mathrm{FRP}$ 製標準サイズ
$\mathrm{D}:$ 金属製オーバーサイズ
$\mathrm{E}: F R P$ 製オーバーサイズ

表 2 素材とフレーム面積の適合について

\begin{tabular}{c|c|c|c|c}
\hline フレーム面積 & $\begin{array}{c}\text { all } \\
\text { CFRP }\end{array}$ & $\begin{array}{c}\text { CFRP } \\
\text { +FRP }\end{array}$ & FRP & Wood \\
\hline 大 $\left(620 \mathrm{~cm}^{2}\right.$ 以上 $)$ & $\bigcirc$ & $\bigcirc$ & $\triangle$ & $\times$ \\
中 $\left(560 \sim 610 \mathrm{~cm}^{2}\right)$ & $\bigcirc$ & $\bigcirc$ & $\triangle$ & $\times$ \\
小 $\left(480 \sim 550 \mathrm{~cm}^{2}\right)$ & $\bigcirc$ & $\bigcirc$ & $\bigcirc$ & $\times$ \\
ュンベンショナル & $\bigcirc$ & $\bigcirc$ & $\bigcirc$ & $\bigcirc$ \\
$\left(450 \mathrm{~cm}^{2}\right.$ 以下 $)$ & $\bigcirc$ & & \\
\hline
\end{tabular}


ては代表的なオーバーサイズラケットの断面図を示す(図 9). その他，素材面でのハイブリッド化は，高級機種ほ ど CFRP の割合が多く, 普及品になるにつれ GFRP が 多く使われてくる．これは一にコスト要因による.

カーボン以外の素材として, アラミド繊維, ボロン繊 維, 更にはシリカ繊維や, セラミックのウィスカーも一 部には使われている.

\section{3 ゴルフクラブ}

ゴルフクラブへの要求を集約すると,

i ）飛距離が優れていること

ii ）ボールとへッドのインパクトのばらつきに対し て飛行方向のずれが小さいこと

の二点にしばられる。

飛距離はクラブヘッドのスピードをいかにアップする かにかかっている.このことは，ゴルファーの運動エネ ルギーをスイングの初めから衝突までに，いかに引き出 し，しかもへッドにどのように効率よく伝達するかにあ る.クラブ全体がもつ運動エネルギーの中で, ヘッド部 がもつ運動エネルギーを少しでも多くするためにはシャ フト部の質量を少しでも小さくすることである.

ここで，ゴルフクラブの各素材と，その結果得られる

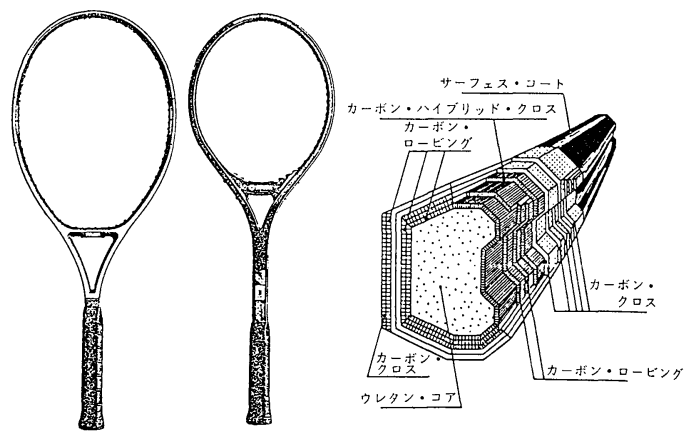

図 9 オーバーサイズラケットとコンベンショナル ラケットの比較，及びオーバーサイズラケッ トの断面図
ヘッドスピードと, キャリーについて比較してみよら（表 3). 素材としては，CFRPが現在では最も適した材料で あることが実験結果からも裏付忷られた。

次に方向性についてであるが，インパクト時にヘッド とボールの相互の重心がずれた場合, ヘッドの重心のま わりに回転が生ずる. その結果方向が狂うことになる. この問題を改良するには, ヘッドの重心のまわりの慣性 二次モーメントを大きくしてやることである. CFRP の 比強度・比弾性の大きなメリットを生かし, 中空構造に 設計すると，表 4 のごとき結果を得る，CFRPによる中 空構造は, シェルの重量分布, 材料構成の選び方が設計 のポイントとなり，製造技術がその品質を決める.

\section{6.あとがき}

スポーツ用具の研究は堀り下げれば限りなく深い。各 個人の固有性の差に加えて, 使用条件が異なるからであ る.これらのことを全部インテグレートして, 商品の多 くは作られているが，実際にはその用具の挙動も，人間 の動きも，理論的に最適解を求めるには不可能に近い.

しかし，人間がよいものを求める欲求がある限り，こ の分野の研究は, 遅々としてではあるが今後進むものと 思われる。

多くのプラスチック材料が複合最適化の過程で検討さ れ，あるものは生き残り，あるものは消えていった。

表 4 ヘッド材料の種類（慣性二次モーメント差）によ る飛距離と方向のズレ

\begin{tabular}{|c|c|c|c|c|}
\hline \multirow{2}{*}{$\begin{array}{l}\text { テストクラブ } \\
\text { のヘッド }\end{array}$} & \multirow{2}{*}{ 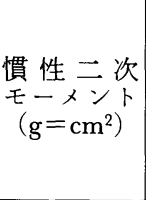 } & \multirow{2}{*}{$\begin{array}{c}\text { 芯でイン } \\
\text { パクトの } \\
\text { 飛 距 離 } \\
(\mathrm{m})\end{array}$} & \multicolumn{2}{|c|}{$\begin{array}{l}\text { 芯より } 15 \mathrm{~m} / \mathrm{m} \\
\text { トウ寄りインパ } \\
\text { クト }\end{array}$} \\
\hline & & & $\begin{array}{c}\text { 飛距離 } \\
(\mathrm{m})\end{array}$ & $\begin{array}{c}\text { 方向の } \\
x_{(\mathrm{m})}\end{array}$ \\
\hline パーシモン A & 2,100 & 196 & 182 & 31 \\
\hline ステンレス鋼 B & 2,150 & 198 & 193 & 15 \\
\hline 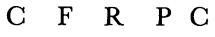 & 2,700 & 207 & 204 & 9 \\
\hline
\end{tabular}

表 3 シャフト材料の種類（重量差）によるヘッドスピード及びキャリ一差の比較

\begin{tabular}{|c|c|c|c|c|c|c|c|}
\hline $\begin{array}{l}\text { テスト } \\
\text { クラブ }\end{array}$ & 使用シャフト & $\begin{array}{l}\text { シ } \\
\text { 重 } \\
\end{array}$ & $\begin{array}{ccc}\text { ヘ重 } & \text { ド } \\
& \text { 量 }\end{array}$ & \begin{tabular}{cccc}
\multicolumn{1}{c}{ グ } & リ & プ \\
重 & & 量 \\
& $(\mathrm{g})$ &
\end{tabular} & 全 $\frac{\text { 重 }}{(\mathrm{g})}$ 量 & ス ピード & $\begin{array}{l}\text { \#1に対する } \\
\text { キャリー差 }\end{array}$ \\
\hline$\# 1$ & 標準スチール & 119 & 210 & 45.6 & 378.6 & 46.1 & - \\
\hline$\# 2$ & 軽量スチール & 86 & 210 & 45.6 & 345.6 & 47.6 & $+6 \mathrm{~m}$ \\
\hline$\# 3$ & $\begin{array}{llll}C & F & R & P\end{array}$ & 77 & 210 & 45.6 & 336.6 & 48.1 & $+8 \mathrm{~m}$ \\
\hline$\# 4$ & 軽量 C F R P & 55 & 210 & 45.6 & 314.6 & 48.8 & $+11 \mathrm{~m}$ \\
\hline
\end{tabular}

クラブ長さ：43インチ スイングマシン：TRUE TEMPER 社製 スイングロボット 
今後の方向は，総合的にはコストパーフォマンスのよ い商品を作ることが最重要課題である．その視点からの 要求は，製造法絡みのものの傾向が強くなると思われる.

一方, よいものを求める欲求が一部には強く, 新素材 の応用研究は，ますます盛んになり，性能向上の可能性
があれば，少々高いコストになっても採用されるものと 思われる。

付記 本報は，日本ゴム協会第24回夏期講座で発表した ものである.

ゴム工業技術員会衛生特別委員会において，とりまとめた技術資料を御希望の方におわけいたします。本会図書係 あてお申込み下さい，御送金は現金書留か郵便振替（東京9-48393）にてお願いいたします.

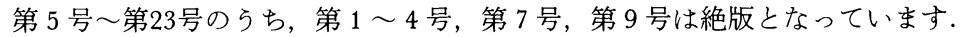

\begin{tabular}{|c|c|c|c|c|}
\hline No. & 題 & 定 価 & 会員特価 & 送料 \\
\hline 第24号 & ゴム製品の安全衛生に関する文献抄訳集UIII（1972～1975） & 4,500 & 4,000 & 400 \\
\hline 第25号 & ゴム製品の安全衛生に関する文献抄訳集 X （1972～1976） & 3,000 & 2,500 & 400 \\
\hline 第26号 & ゴム製品の安全衛生に関する文献抄訳集X（1973～1977） & 3,500 & 3,000 & 350 \\
\hline 第27号 & ゴム製品の安全衛生に関する文献抄訳集 XI （1975～1977） & 1,800 & 1,500 & 350 \\
\hline 第28号 & ゴム製品の安全衛生に関する文献抄訳集 XII（1974～1978） & 4,000 & 3,500 & 400 \\
\hline 第29号 & ゴム製品の安全衛生に関する文献抄訳集 XIII（1975～1978） & 4,500 & 4,000 & 400 \\
\hline 第30号 & ゴム製品の安全衛生に関する文献抄訳集 XN（1972～1978） & 3,500 & 3,000 & 350 \\
\hline 第31号 & ゴム製品の安全衛生に関する文献抄訳集 XV（1977～1979） & 3,500 & 3,200 & 350 \\
\hline 第32号 & ゴム製品の安全衛生に関する文献抄訳集 XV（1975～1980） & 4,500 & 4,000 & 400 \\
\hline 第33号 & ゴム製品の安全衛生に関する文献抄訳集 XVII（1975～1980） & 3,500 & 3,200 & 350 \\
\hline 第34号 & ゴム製品の安全衛生に関する文献抄訳集 XVII（1979～1980） & 4,500 & 4,000 & 400 \\
\hline 第35号 & ゴム製品の安全衛生に関する文献抄訳集 XX（1977～1980） & 3,500 & 3,200 & 350 \\
\hline 第36号 & ゴム製品の安全衛生に関する文献抄訳集 XX（1975～1981） & 3,500 & 3,000 & 350 \\
\hline 第37号 & ゴム製品の安全衛生に関する文献抄訳集XXI （1981～1982） & 3,500 & 3,000 & 350 \\
\hline 第38号 & ゴム製品の安全衛生に関する文献抄訳集 XXII（1980～1981） & 3,500 & 3,000 & 300 \\
\hline 第39号 & ゴム製品の安全衛生に関する文献抄訳集 XXIII（1981～1982） & 4,000 & 3,500 & 300 \\
\hline 第40号 & ゴム製品の安全衛生に関する文献抄訳集 XXN （1982） & 3,500 & 3,000 & 300 \\
\hline 第41号 & ゴム製品の安全衛生に関する文献抄訳集 XXV（1982～1983） & 4,500 & 4,000 & 350 \\
\hline 第42号 & ゴム製品の安全衛生に関する文献抄訳集XXV（1970～1973） & 4,500 & 4,000 & 400 \\
\hline$P L$ & ゴム製食品用器具及び容器包装等に関するポジティブリスト(第 3 版) & 3,000 & 2,400 & 300 \\
\hline
\end{tabular}

